\title{
A study of lymphocytotoxins in families of patients with systemic lupus erythematosus
}

\author{
RON A. HAZELTON \\ From the University Department of Medicine, Centre for Rheumatic Diseases, and the Department of Clinical \\ Immunology, Glasgow Royal Infirmary, Glasgow
}

SUMMARY Lymphocytotoxic antibodies are a common feature in the sera of patients with systemic lupus erythematosus. This family study, however, has not confirmed the previous findings of an increased incidence in the sera of their relatives. Adsorption studies suggest that when lymphocytotoxins occur in the sera of normal subjects and relatives of patients they have a different specificity and thus significance.

Lymphocytotoxins have been found in a large number of conditions including viral illnesses, ${ }^{1}$ malignancy, ${ }^{2}$ multiple sclerosis, ${ }^{3}$ organ transplantation, following pregnancy, and after a variety of immunising procedures including vaccination. ${ }^{4}$ They are recognised to occur in high titre in patients with systemic lupus erythematosus (SLE) and to a less extent in rheumatoid arthritis. ${ }^{5}$ Since lymphocytotoxins occur in viral illness, though only for a short time, the concept has arisen that a virus or viruses may be of aetiological importance in SLE. ${ }^{6}$ Some family studies of patients with SLE examining the incidence of lymphocytotoxic antibodies in patients, and in consanguineous and nonconsanguineous contacts have demonstrated a significant increase in lymphocytotoxins in the latter 2 groups compared with normal control subjects. ${ }^{7-12}$ But other investigators have not confirmed these findings. ${ }^{13} 14$

In order to elucidate further the incidence and nature of lymphocytotoxins in SLE, particularly with regard to their antigenic and temperature specificity, a family study has been undertaken.

\section{Subjects and methods}

SLE PATIENIS AND FAMILIES

Sixteen families in whom one individual met the ARA criteria ${ }^{15}$ for classification of SLE were studied. In addition there were 15 other patients with SLE, whose families were not studied, making a total of 31 patients. All patients and their relatives came from

Accepted for publication 14 March 1983.

Correspondence to Dr R. A. Hazelton, Department of Medicine, Princess Alexandra Hospital, Ipswich Road, Brisbane 4102, Australia. the same geographical area and belonged to the one ethnic group. The consanguineous relatives were parents, siblings, children, and cousins while the nonconsanguineous relatives were spouses and parentsin-law. All families were visited in their homes, and over $85 \%$ of first-degree relatives were included in the study. Relatives were questioned and examined for the possibility of previously undetected rheumatic disease. All patients had clinical evidence of disease activity at the time of study and suffered from a wide variety of clinical manifestations.

Control subjects (22 female and 16 male) were selected because they had no contact with the patients and were not hospital staff. As a group the female controls were the same age and parity as the patients with SLE. All subjects were questioned on a history of previous blood transfusion and recent viral infection or vaccination.

\section{METHODS}

1. Lymphocytotoxicity assay. The sera from each subject were stored at $-20^{\circ} \mathrm{C}$ in aliquots until used. The presence of cold lymphocytotoxic antibodies was investigated by means of the microdroplet cytotoxicity assay of Terasaki and McClelland. ${ }^{16}$ The sera were coded and randomised so that they were assayed blind. An AB serum negative control was included in each assay. All sera were reacted in duplicate against lymphocytes from 33 normal panel subjects. Approximately 2000 lymphocytes were incubated with $1 \mu \mathrm{l}$ of neat serum at either $15^{\circ} \mathrm{C}$ or $4^{\circ} \mathrm{C}$. After the addition of $5 \mu \mathrm{l}$ of rabbit complement (Buxted Rabbit Co., UK Ltd) the incubation continued for a further hour at room temperature (approximately $20^{\circ} \mathrm{C}$ ).

2. HLA typing. The lymphocytes from the 33 normal panel subjects were tissue typed by microdroplet 
lymphocytotoxicity assay. ${ }^{17}$ HLA typing sera had specificities for HLA A, B, and C antigens.

3. Adsorption assay. Six different types of adsorbing tissue were used. Heterophile antibodies were tested for and are of 3 known types. Forsmann antibodies are characterised by adsorption by both sheep red cells and homogenised guinea-pig kidney tissue..$^{18-20}$ Paul-Bunnell heterophile antibodies are known to be adsorbed by sheep and ox red cells but not by guinea-pig kidney tissue. ${ }^{2122}$ The third heterophile antibody system originally described by Hanganutziu ${ }^{23}$ and Deicher ${ }^{24}$ is adsorbed by sheep and ox red cells and guinea-pig kidney tissue. ${ }^{25} \mathrm{RhO}+\mathrm{ve}$ adult red cells are known to contain the $I$ antigen system. In contrast fetal cord $\mathrm{RhO}$ - ve red cells are known to possess predominantly $\mathrm{i}$ as opposed to I antigen in adults. ${ }^{26}$ Pooled date-expired platelets are known to possess not only $\mathrm{ABO}$ and $\mathrm{Rh}$ blood group substances but also the human leucocyte antigens belonging to the HLA A, B, and C series but not the HLA DR. ${ }^{17}$

Each adsorbing tissue was washed separately in phosphate buffered saline 3 times. The sera for adsorption were chosen because they were observed to be strongly lymphocytotoxic. Two separate aliquots of each sera were mixed with an equal volume of the washed adsorbing tissue, either cell or tissue homogenate, incubated at either $4^{\circ} \mathrm{C}$ or $15^{\circ} \mathrm{C}$. This adsorbing step was repeated 3 times. The thrice adsorbed sera were then tested for lymphocytotoxicity. A full set of the 5 unadsorbed sera and an $\mathrm{AB}$ serum negative control were included in each assay with the adsorbed sera.

\section{Results}

1. Lymphocytotoxicity. The lymphocytotoxic data were analysed after allotting a value for cytotoxic index ${ }^{3}$ for each sera at the 2 reacting temperatures of $15^{\circ} \mathrm{C}$ and $4^{\circ} \mathrm{C}$. The cytotoxic index $=$

average percentage lymphocytotoxicity of test serum - negative control

average percentage cytotoxicity of known positive control -

negative control

The positive control was the serum from an SLE patient with the greatest number and intensity of lymphocytotoxic reactions. The cytotoxic index makes allowances for batch to batch variation in results. Reactions of $5 \%$ or more were regarded as being positive, as $97.3 \%$ of normal controls had reactions less than this. By $\chi^{2}$ analysis with Yates's correction patients with SLE were found to have significantly more reactions- $48.4 \%$ at $15^{\circ} \mathrm{C}$ $(\mathrm{p}<0.001)$ and $41.9 \%$ at $4^{\circ} \mathrm{C}(\mathrm{p}<0.001)$ - than the normal controls (Table 1 ).

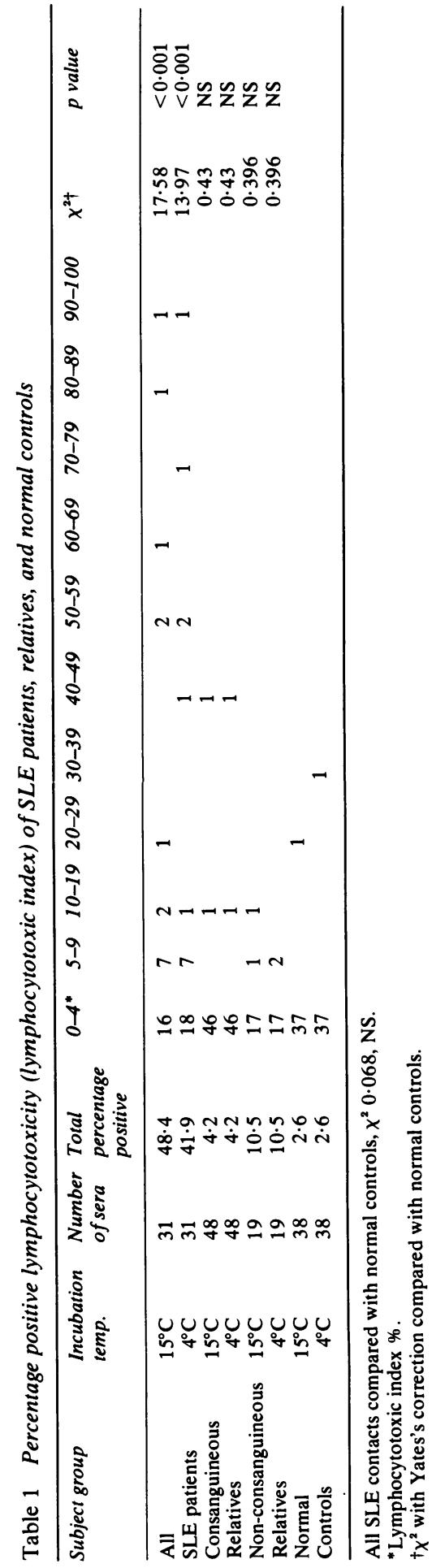


Table 2 Percentage of lymphocytotoxicity adsorbed

\begin{tabular}{|c|c|c|c|c|c|c|c|c|c|c|c|c|}
\hline & \multicolumn{2}{|l|}{ Sheep } & \multicolumn{2}{|l|}{$O x$} & \multicolumn{2}{|c|}{ Guinea-pig } & \multicolumn{2}{|c|}{$\begin{array}{l}\text { Adult } R h O \\
+v e \text { red cells }\end{array}$} & \multicolumn{2}{|c|}{ Platelet } & \multicolumn{2}{|c|}{$\begin{array}{l}\text { RhO - ve fetal } \\
\text { cord red cells }\end{array}$} \\
\hline & $4^{\circ} \mathrm{C}^{*}$ & $15^{\circ} \mathrm{C}$ & $4^{\circ} \mathrm{C}$ & $15^{\circ} \mathrm{C}$ & $4^{\circ} \mathrm{C}$ & $15^{\circ} \mathrm{C}$ & $4^{\circ} \mathrm{C}$ & $15^{\circ} \mathrm{C}$ & $4^{\circ} \mathrm{C}$ & $15^{\circ} \mathrm{C}$ & $4^{\circ} \mathrm{C}$ & $15^{\circ} \mathrm{C}$ \\
\hline \multirow[t]{3}{*}{ SLE } & 33 & 19 & 15 & 0 & 22 & 36 & 53 & 69 & 78 & 85 & 41 & 43 \\
\hline & 53 & 16 & 41 & 64 & 54 & 29 & 54 & 0 & 62 & 18 & 55 & 66 \\
\hline & 0 & 0 & 3 & 91 & 10 & 16 & 3 & 3 & 11 & 3 & 3 & 7 \\
\hline $\begin{array}{l}\text { Sister of SLE } \\
\text { patient }\end{array}$ & 0 & 0 & 0 & 0 & 0 & 0 & 0 & 0 & 100 & 100 & 9 & 0 \\
\hline Control & 13 & 20 & 0 & 57 & 11 & 14 & 100 & 100 & 100 & 70 & 13 & 41 \\
\hline
\end{tabular}

${ }^{*}$ Represents temperature at which serum was adsorbed.

Analysis of the data for consanguineous and nonconsanguineous relatives of patients with SLE did not reveal any significant differences from the control. Three of the 4 patients with SLE whose relatives had lymphocytotoxins similarly were found to have lymphocytotoxins in their sera.

2. HLA tissue typing. Reactions of the sera were compared with those found with the HLA typing sera. There was no association between the cold lymphocytotoxins and any of the HLA specificities identified on the lymphocytes of the normal panel subjects.

3. Adsorption study. In one family both a patient and his sister had lymphocytotoxins in their sera. However, this patient's sister had her lymphocytotoxins adsorbed by platelets at both $4^{\circ} \mathrm{C}$ and $15^{\circ} \mathrm{C}$. A control subject with lymphocytotoxins exhibited strong adsorption with platelets and adult $\mathrm{RhO}$ + ve red cells at both temperatures. Sera from patients with SLE tended to react with the majority of the adsorbing tissues (Table 2).

\section{Discussion}

The results of this study have confirmed the significantly increased incidence of lymphocytotoxic reactions in the sera of patients with SLE. However, an increased incidence of lymphocytotoxic reactions was not found in consanguineous and nonconsanguineous relatives of patients with SLE as reported by others. ${ }^{7-1012}$ A number of explanations could account for these differing results. In the present study the majority of patients had clinical evidence of disease activity when they were studied. Previous studies have given little indication of the type of clinical disease their patients suffered from as it has been reported that the highest cytotoxicity occurs in patients with CNS involvement. ${ }^{27}$ At least one study reported a very high incidence of lymphocytotoxins in the control groups as well as relatives. ${ }^{10}$ This would suggest that there may be a high background of lymphocytotoxins of whatever aetiology in the sera of that community.
The pathogenic role, if any, of lymphocytotoxins in the sera of patients with SLE is poorly understood. It has been suggested that those lymphocytotoxins which react with cerebral tissue may be of use in monitoring CNS involvement in this disease. ${ }^{28}$

Another study has reported a significant reduction in lymphocy totoxicity after adsorption with fetal cord red cells, and this was taken as evidence for predominantly i specificity in the sera of patients with SLE. ${ }^{29}$ However, in the present study the 3 sera from patients with SLE gave strong reactions with many different tissue antigens, and there was no evidence for predominant $i$ activity. There was no evidence that the lymphocytotoxins had anti-HLA activity as had been reported previously. ${ }^{11}$

The lymphocytotoxins in the serum of a relative of a patient with SLE were totally adsorbed by the platelet extract. This is evidence that these lymphocytotoxins were not of the same aetiology as those found in the sera of patients with SLE.

In summary, this study has not found an increased incidence of lymphocytotoxins in the sera of close contacts of patients with SLE. When they did occur in a consanguineous relative the adsorption pattern was consistent with their being active against some blood group substance and not having broad reactivity, as was the case of the lymphocytotoxins found in the sera of patients with SLE. This is strong evidence against the lymphocytotoxins in the sera of relatives and patients with SLE having a common aetiology.

I thank Professor Heather M. Dick and the staff of the Department of Clinical Immunology, Glasgow Royal Infirmary, Glasgow, and the many consultants who permitted me to study patients under their care. Thanks also to the patients and their relatives for co-operating in this study.

\section{References}

1 Mottironi V D, Terasaki P I. In: Terasaki P I, ed. Lymphocytotoxins in disease. Infectious mononucleosis, rubella and measles. Histocompatability Testing 1970. Copenhagen: Munksgaard, 1970: 301-8. 
2 Mendius J R, De Horatius R J, Messner R P, Williams R C. Family distribution of lymphocytotoxins in Hodgkin's disease. Ann Intern Med 1976; 84: 151-6.

3 Schocket A L, Weiner H L. Lymphocytotoxic antibodies in family members of patients with multiple sclerosis. Lancet 1978 ; i: 571-3.

4 Naito S, Mickey M R, Hirota A, Terasaki P I. Autolymphocytotoxins following immunization by pregnancy, transplantation and disease. Tissue Antigens 1971; 1: 219-28.

5 Ozturk G, Terasaki P I. Non-HLA lymphocyte cytotoxins in various diseases. Tissue Antigens 1979; 14: 52-8.

6 Terasaki P I, Mottironi V D, Barnett E V. Cytotoxins in disease. Autocytotoxins in lupus. N Engl J Med 1970; 283: 724-8.

7 De Horatius R J, Messner R P. Lymphocytotoxic antibodies in family members of patients with systemic lupus erythematosus J Clin Invest 1975; 55: 1254-8.

8 Malavé I, Papa R, Layrisse Z. Lymphocytotoxic antibodies in SLE patients and their relatives. Arthritis Rheum 1976; 19; $700-4$.

9 Messner R P, De Horatius R J. Epidemiology of antilymphocyte antibodies in systemic lupus erythematosus. Arthritis Rheum 1978; 21: S167-70.

10 Folomeeva $\mathrm{O}$, Nassonova V A, Alekberova A S, Talal N, Williams R C. Comparative studies of antilymphocyte, antipolynucleotide, and antiviral antibodies among families of patients with systemic lupus erythematosus. Arthritis Rheum 1978; 21: 23-7.

11 Messner R P, De Horatius R J, Ferrone S. Lymphocytotoxic antibodies in systemic lupus erythematosus patients and their relatives. Reactivity with the HLA antigen molecular complex. Arthritis Rheum 1980; 23: 265-72.

12 Dawkins R L, Witt C, Richmond J, Sagenschneider K, Zilko P J. Lymphocytotoxic antibodies in disease. Aust NZ J Med 1978; suppl 1: 81-6.

13 Cleland L G, Bell D A, Williams M, Saurino B C. Familial lupus. Family studies of HLA and serologic findings. Arthritis Rheum 1978; 21: 183-91.

14 Browning J D, Dick H M, Sturrock R, Grennan D, Dick W C Cold lymphocytotoxins in connective tissue disorders. Scot Med J 1979; 24: 5-8.
15 Tan E M, Cohen A S, Fries J F, et al. The 1982 revised criteria for the classification of systemic lupus erythematosus. Arthritis Rheum 1982; 25: 1271-7.

16 Terasaki P I, McClelland J D. Microdroplet assay of human serum cytotoxins. Nature 1964; 204: 998-1000.

17 Dick H M, Kissmeyer-Nielson F, eds. In: Histocompatability techniques. North Holland: Elsevier, 1980.

18 Forsmann J. Die herstellung hochwertiger spezifischer schäfhämolysine ohne verwendung von Schafblut. Biochem $Z$ 1911; 37: 78-82.

19 Milgrom F, Kano K, Fjelde A, Bloom M L. Heterophile antigens and antibodies in transplantation and tumors. Transplant Proc 1975; 7: 201-7.

20 Schiff F, Adelsberger L. Ueber blutgruppenspezifische antikörper und antigene. Immuno Forsch 1924; 40: 335-67.

21 Paul J R, Bunnell W W. Presence of heterophile antibodies in infectious mononucleosis. Am J Med Sci 1932; 183: 90-104

22 Davidsohn I, Walker P H. Nature of heterophile antibodies in infectious mononucleosis. Am J Clin Pathol 1935; 5: 455-65.

23 Hanganutziu $M$. Hémagglutinines hétérogénétiques apres injection de serum de chevol. C R Soc Biol (Paris) 1929; 91: 1457-9.

24 Deicher $H$. Über die Erzeugung heterospezifischer Haemagglutinine durch Injektion artfremden Serums. $Z$ Hyg 1926; 106: 561-679.

25 Kasukawa R, Kano K, Bloom M L, Milgroom F. Heterophile antibodies in pathologic human sera resembling antibodies stimulated by foreign species sera. Clin Exp Immunol 1976; 25: 122-32.

26 Shumak K H, Rachkewich R A, Crookston M C, Crookston T H. Antigens of Ii: system on lymphocytes. Nature: New Biol 1971; 231: 148-9.

27 Bresnihan B, Grigor R R, Hughes G R V. Lymphocytotoxic antibodies in systemic lupus erythematosus: their clinical significance.J Clin Pathol 1979; 13 (suppl 32): 112-5.

28 Bluestein H G, Zvaifler N J. Brain-reactive lymphocytotoxic antibodies in the serum of patients with systemic lupus erythematosus. J Clin Invest 1976; 57: 509-16.

29 Goldberg L S, Bresnihan B, Hughes G R V. Lymphocytotoxic antibodies in systemic lupus erythematosus: evidence for reactivity with i antigen. Clin Exp Immunol 1978; 31: 443-7. 